\title{
КОНЦЕПТОСФЕРА «ФАНТАЗИЯ» В ФОЛЬКЛОРНО-ЯЗЫКОВОЙ КАРТИНЕ МИРА (НА МАТЕРИАЛЕ ИСПАНСКОЙ ВОЛШЕБНОЙ СКАЗКИ)
}

\section{THE CONCEPT SPHERE «FANTASY» IN THE FOLKLORE AND LANGUAGE PICTURE OF THE WORLD (BASED ON THE MATERIAL OF THE SPANISH FAIRY TALE)}

N. Zenenko L. Son

Summary: The paper analyzes the mental concepts «time» and "spatial localization" that make up the folklore concept sphere "fantasy" and determine the essential beginning of the folklore-linguistic picture. Modern linguo-cognitive postulates made it possible to describe the selected concepts and note the heterogeneity of their lexical and semantic structures. The virtual representation of the real world forms the basis of the "fantasy" concept sphere in the folklore-linguistic picture of the Spanish-speaking world.

Keywords: folklore-linguistic picture, concept-sphere, concept, lexicalsemantic structure.

\author{
Зененко Наталья Викторовна \\ Д.филол.н., профессор, Военный университет \\ Министерства обороны РФ (2. Москва) \\ zenenko@mail.ru \\ Сон Людмила Петровна \\ К.э.н., доцент, Военный университет \\ Министерства обороны РФ (2. Москва) \\ luciason@mail.ru
}

Аннотация: В работе проводится анализ ментальных концептов «время» и «пространственная локализация», составляющих фольклорную концептосферу «фантазия» и определяющих сущностное начало фольклорно-языковой картины. Современные лингвокогнитивные постулаты позволили описать выбранные концепты и отметить неоднородность их лексико-семантических структур. Виртуальное представление о реальном мире составляет основу концептосферы «фантазия» в фольклорно-языковой картине испанноязычного мира.

Ключевые слова: фольклорно-языковая картина, концептосфера, концепт, лексико-семантическая структура.
$\mathrm{T}$ ермин «картина мира» в научных исследованиях которые проводятся в рамках когнитивной лингвистики, является одним из базовых понятий. Понятие «картина мира» активно эксплуатируется в современном научном познании. Один из крупнейших философов XX века М. Хайдеггер, размышляя о сущностных явлениях современности, рассуждает также о картине мира. Немецкий мыслитель полагает, что картина мира это не только «полотно сущего в целом», а нечто большее. Картина мира, по его мнению, это сам мир, «сущее в целом»; то, что «слышится в обороте речи» [5].

Картина мира многогранна, а система представлений человека о мире изменчива. Суждения мыслящего индивида могут меняться в зависимости от трансформаций познающего им окружающего мира. Одним из проявлений картины мира является языковая картина мира, которая формируется на базе национальных исторических, духовных и этнокультурных ценностей.

В основе фольклорно-языковой картины мира лежит коллективная ментальность нации, которая, в свою очередь, является хранилищем нравственных идеалов, когнитивных устремлений, общесоциальных компетенций.

По мнению некоторых филологов, термин фольклор был введен в научный обиход в 1846 году британским писателем Джоном Томсом (англ. William John Thoms) [7]. Дж. Томс использовал этот термин в целях унификации уже существующих понятий, включающих в себя представления человека об окружающем его мире, основанные на мифологических сюжетах и языческих верованиях определенного этноса.

Будучи неотъемлемой частью культурного наследия любого народа, фольклор насчитывает немало течений, жанров, которые, переплетаясь между собой, влияя друг на друга и, в то же время, дополняя друг друга, в целом и определяют фольклор как целостное понятие.

В отечественной научной литературе существует немало дефиниций фольклорно-языковой картины мира (О.А. Петренко, Б.Н. Путилов, К.В. Чистов, И.П. Черноусова и др.). Мы, со своей стороны, трактуем фольклорноязыковую картину мира как виртуальное представление о реальном мире, формирование которого осуществлялось посредством семантического перекодирования, что приводит, в свою очередь, к становлению этнической культуры как «системы смыслов» [2] отдельной нации.

Волшебная сказка, являясь культурным наследием, не только воспроизводит самобытность и уникаль- 
ность нации, но и, будучи одним из основных жанров фольклорной прозы, представляет собой особую форму отображения действительности в общей системе языка. Являясь древнейшим литературным жанром, сказка уходит своими корнями далеко вглубь каждого отдельно взятого народа. Как отмечает основоположник сравнительно-типологического метода в фольклористике В.Я. Пропп, древние полеводческие, охотничьи обряды породили базовый миф, который, в свою очередь, явился источником появления сюжетов для сказок [4].

Сказка несет в себе установку на вымысел: «Сказка ложь, да в ней намек, добрым молодцам урок!» - сказал А.С. Пушкин, фраза приобрела популярность и стала выразителем жизненного опыта и национальной мудрости. Волшебная сказка - это когнитивный феномен, в основе которого лежит «передача знания» и «переработка знания» для его использования в определенных целях [1].

Внутреннее единство сказки определяется ее тематическими и концептуальными параметрами. Одним из факторов внутреннего единства любого текста являются концепты. Концепты подчиняют себе все единицы текста в их динамике и статике. Высокая степень реализации смысловой насыщенности и познавательной практики в волшебной сказке расширяет новый диапазон разнообразных практик концептуализации, что позволяет нам интерпретировать их характеристики с точки зрения онтологической сущности этнического мира. Концептуальные структуры сказки могут действовать «как более или менее мощные средства убеждения, то есть как стратегические средства воздействия на предпочтительные ментальные модели» [6].

Настоящий анализ предполагает описание ментальных концептов «время» и «пространственная локализация», составляющих фольклорную концептосферу «фантазия», на базе которой устанавливается сущностное начало фольклорно-языковой картины. С лингвокогнитивных позиций (С.А. Аскольдов-Алексеев 1928, Д.С. Лихачев 1997, Ю.С. Степанов 2001, А. Вежбицкая 2001, В.И. Карасик 2002, Е.С. Кубрякова 2003 и др.) общепризнанным является следующее понимание термина концептосфера - набор ключевых концептов, объединенных единой тематикой. «Чем меньше культурный опыт человека, тем беднее не только его язык, но и концептосфера его словарного запаса...» [3].

Остановимся на описании лексико-семантической структуры концепта «время». Концепт «время», как одна из основных категорий бытия, относится к базовым философским понятиям, является универсальным и занимает центральное место в фольклорно-языковой картине мира.

В исследовании был проведен анализ волшебных испанских сказок, на основании которого мы выделили две лексико-семантические группы.

Первая группа - «определенное время», в ее состав входят лексемы, семантика которых указывает на определенный отрезок времени. Например: у еso un día y otro (исп.) - этот день и следующий (русск.); todos los días (исп.) - всё время (русск.); у otro día (исп.) - на следующий день (русск.); pasados unos días (исп.) - спустя какоето время (русск.); pasaron varios días (исп.) - прошли дни (русск.); duraron varios meses (исп.) - на протяжении нескольких месячев (русск.); muchos años, muchísimos años (исп.) - много лет (русск) и др.

По своей семантике единицы данной лексико-семантической группы можно разделить на три подгруппы:

1. с гиперсемой «día»- у еso un día y otro; todos los días, y otro día; pasados unos días; un día; al día siguiente; pasaron varios días.

2. с гиперсемой «meses»: duraron varios meses; pasaron los meses.

3. с гиперсемой «аño»: muchos, muchísimos años.

Вторая группа - «неопределенное время», в ее состав входят лексемы, семантика которых указывает на неопределенный отрезок времени. Например: erase una vez (исп.) - однажды (русск.); у еso un día y otro (исп.) - этот день и следующий (русск.); у otro día (исп.) - на другой день (русск.); hace muchos, muchísimos años (исп.) - спустя много, много лет (русск.); ya va siendo hora (исп.) - наступило время (русск.); de momento (исп.) - в момент (русск.); la hora de cenar (исп.) - в часужина (русск.); en aquel momento (исп.) - в тот момент (русск.); al día siguiente (исп.) - на следующий день (русск.); duraron varios meses (исп.) - в течение нескольких месячев (русск.); al росо tiemро (исп.) за короткий срок (русск.); al momento (исп.) - к моменту (русск.); en ese momento (исп.) - в этот момент (русск.); pasaron varios días (исп.) - прошли дни (русск.); había una vez (исп.) - однажды (русск.); pasaron los meses (исп.) - cnyстя месяцы (русск.) и др.

Лексические единицы данной группы можно разделить на три подгруппы:

1. с гиперсемой «vez» - erase una vez; otra vez; había una vez.

2. с гиперсемой «tiempo» - por aquel tiempo; al mismo tiempo; amenizaban el tiempo; así ahorraríamos mucho tiempo; poco tiempo.

3. с гиперсемой «momento» - había llegado el momento; de momento, en aquel momento; al momento, en ese momento.

Полученные данные позволяют сделать вывод о том, что в испанских волшебных сказках, практически в равной степени, используются языковые формулы как с неопределёнными временными рамками, так и с опре- 
делённым временными рамками. Итак, представляется возможным отметить, что лексико-семантическая структура концепта «время» неоднородна.

Также рассмотрим лексико-семантическую структуру концепта «пространственная локализация». Философская категория «пространство» - это универсальная категория, однако, вербализация пространственных отношений в разных языках происходит неодинаково. Разнообразные факторы - культурно-генетический код нации, условия развития социума и многие другие - во многом определяют характер восприятия пространственно-временного континуума и локализацию субъекта и предмета в нем.

Концепт «пространственная локализация» является базовым при формировании когнитивного понимания у человека при обозначении различного типа пространственных связей между объектами реальной действительности. В фольклорно-языковой картине мира данный концепт, наряду с концептом «время» занимает одно из центральных мест.

На основании проделанного лексико-семантического анализа волшебных испанских сказок нами были выделены две противопоставленные друг другу лексико-семантические группы. Первая группа с гиперсемой «реальный мир»: en una posada (исп.) - в постоялом двоpe (русск.); en las afueras (исп.) - в окрестностях (русск.); en la corte (исп.) - при дворе (русск.); las caballerizas (исп.) - конюшни (русск.); el castillo (исп.) - замок (русск.); uno de los barrios pobres del reino (исп.) - один из беднейших кварталов королевства (русск.);en la plaza central (исп.) - на чентральной площади (русск.).

Вторая группа с гиперсемой «нереальный мир»: era una tierra muy lejana (исп.) - дальняя земля (русск.); un campo que nada más entrar (исп.) - место, куда ещё ни- кто не ступал (русск.); un sitio muy peligroso (исп.) - очень onacное место (русск.).

Кроме того, мы выделяем две семантические подгруппы, единицы которых могут мигрировать из реального мира в нереальный. Первая подгруппа с гиперсемой «королевство»: en el salón del trono (исп.) - тронный зал (русск.); el castillo (исп.) - замок (русск.); el reino (исп.) - королевство (русск.). Вторая подгруппа с гиперсемой «деревня или другое королевство»: una pequeña aldea perdida entre montañas (исп.) - небольшая деревенька, затерянная средь гор (русск.); molino un росо más abajo (исп.)- мельница ниже (по течению) (русск.); el castillo de la Isla (исп.) - замок на острове (русск.).

Таким образом, лексико-семантическая группа с гиперсемой «реальный мир» по количественному составу превышает группу семантическую «нереальный мир». Реальный мир пребывания человека содержит тривиальные наименования строений, частей населенного пункта и т.д., а нереальный мир описывается как опасный, угрожающий, подозрительный, неизведанный. Место действия в реальном мире не имеют конкретной топонимической локализации, страна или город, в котором разворачиваются события, неизвестны. Предполагается, что действия, описываемые в сказке, могут происходить в любой части света.

Из проведенного анализа следует, что «время» и «пространственная локализация» в волшебной испанской сказке являются базовыми понятиями, образующими концептосферу «фантазия». Нами была отмечена неоднородная лексико-семантическая структура концепта «время». Понятия «реальный» и «нереальный» мир находятся в состоянии антагонистической оппозиции. Виртуальное представление о реальном мире составляет основу концептосферы «фантазия» в фольклорно-языковой картине испаноязычного мира.

\section{ЛИТЕРАТУРА}

1. Кубрякова Е.С., Александрова 0.В. Виды пространства текста и дискурса // Категоризация мира: пространство и время. - М., 1997. - С. 15-25.

2. Леонтьев Д.А. Психология смысла: Автореф. дис. ... доктора наук; Психологические науки: 19.00 .11 / Моск. гос. ун-т им. М. В. Ломоносова, Фак. психологии. - М., 1999. -40 с.

3. Лихачев Д.С. «Концептосфера русского языка. М Академия, 1997. С. 152. - [Электронный ресурс] URL: https://docviewer.yandex.ru/view/4031645/?page=1 $\&^{*}=$ CUfD8\%2F48uQwybMfbWW\%2FhMu6dKHZ7InVybCl6Imh0dH (дата обращения 14.03.2021).

4. Пропп В.Я. «Исторические корни волшебной сказки». Л: Изд. ЛГУ, 1996г. - 364 с.

5. Хайдеггер М. Время и бытие: статьи и выступления (пер. с нем.; комм. В.В. Бибихина; серия“"Мыслители XХ в.”). - М., Республика 1993. - стр. 41- 63. [Электронный ресурc] URL: http://www.odinblago.ru/filosofiya/haydegger/khaydegger_m_vremya_kartin/vremya_kartin0 (дата 0бращения 14.03.2021).

6. Van Dijk, T. Análisis del discurso ideológico. Trad. De R. Alvarado. 1996. México: UAM, núm. 6, pp. 15-43.

7. Sims, Martha, Stephens, Martine. Living Folklore. Logan, Utah: Utah State University Press, 2005. - P. 23. 